\title{
PEDAGOGIKA $A_{201019}^{\text {pol } \times \text { XII }}$
} Ni (7) SPOŁECZNA

Rodzicielstwo
- problemy, przestrzenie, formy
Parenthood
- issues, spaces, forms

\author{
Lidia Dakowicz*, Andrzej Dakowicz** \\ Uniwersytet w Białymstoku \\ * ORCID: 0000-001-6424-1370; ** ORCID: 0000-0002-3614-8985 \\ DOI: $10.35464 / 1642-672 X . P S .2019 .1 .09$
}

\section{Postawy rodzicielskie małżonków o wyższym i niższym poziomie samoakceptacji}

\section{Parental attitudes of spouses of higher and lower level of self-acceptance}

\begin{abstract}
A B S TRACT: The study involved 75 families were examined using The Adjective Check List (ACL) by H.G. Gough and A.B. Heilbrun and Family Attitude Scale by M. Braun-Gałkowska. Mothers with a lower level of self-acceptance were more often characterized by an excess of requirements than mothers with a higher level of self-acceptance. The examined children attributed to mothers with a lower level of self-acceptance, much more often the excess of management, than mothers with a higher level of self-acceptance. Fathers with a lower level of self-acceptance were more often characterized by an excess of help than fathers with a higher level of self-acceptance. The obtained results indicate that parental attitudes expressed by the spouses with a higher level of self-acceptance more frequently than the parental attitudes of spouses with a lower level of self-acceptance are characterized by moderation in all dimensions of the parental attitude, which characterizes the proper parental attitude conducive to the proper development of children.
\end{abstract}

KE Y W O R D S: Family sciences, spouses, parental attitudes, level of self-acceptance.

STRESZCZENIE: Badania 75 rodzin przeprowadzono przy użyciu Testu Przymiotnikowego ACL H.G. Gougha i A.B. Heilbruna oraz Skali Postaw Rodzinnych M. Braun-Gałkowskiej. Matki o niższym poziomie samoakceptacji zdecydowanie częściej charakteryzowały się nadmiarem wymagań, niż matki o wyższym poziomie samoakceptacji. Badane dzieci przypisywały matkom o niższym poziomie samoakceptacji zdecydowanie częściej nadmiar kierowania, niż matkom o wyższym poziomie samoakceptacji. Ojcowie o niższym poziomie samoakceptacji zdecydowanie częściej charakteryzowali się nadmiarem pomocy niż ojcowie o wyższym poziomie samoakceptacji. Uzyskane wyniki wskazują, że przejawiane przez małżonków o wyższym poziomie 
samoakceptacji postawy rodzicielskie częściej niż postawy rodzicielskie małżonków o niższym poziomie samoakceptacji, charakteryzują się umiarem we wszystkich wymiarach postawy rodzicielskiej, co jest właściwą postawą rodzicielską sprzyjającą prawidłowemu rozwojowi dzieci.

SŁOWA KLUCZOWE: Nauki o rodzinie, małżonkowie, postawy rodzicielskie, poziom samoakceptacji.

\section{Wprowadzenie}

Człowiek wyraża siebie poprzez złożoną strukturę osobowości, której istotną częścią są wyrobione w trakcie życia postawy społeczne, rozumiane najczęściej jako trwałe dyspozycje procesów poznawczych, emocjonalnych $\mathrm{z}$ tendencją do określonych zachowań wobec danego przedmiotu (Wojciszke, Doliński 2008). Jeżeli weźmiemy pod uwagę środowisko rodzinne, to znaczącą w nim rolę odgrywa relacja pomiędzy rodzicami a dziećmi, która uwarunkowana jest m.in. przejawianą w codzienności postawą rodziców wobec własnych dzieci, określaną w literaturze mianem postawy rodzicielskiej. Postawy rodzicielskie należy rozumieć jako względnie stały stosunek rodzica do dziecka, będący wynikiem posiadanej przez rodzica wiedzy na temat dziecka, emocjonalnego odniesienia rodzica do dziecka powiązanego ze skłonnością do określonych zachowań rodzica wobec dziecka (Braun-Gałkowska 1992; Plopa 2005). Przeniesienie ujęć teoretycznych związanych z postawami rodzicielskimi na grunt życia rodzinnego doprowadziło $\mathrm{w}$ praktyce do powstania różnych typologii (Jankowska 2013; Wilk 2016). Prezentowane opracowanie oparto na typologii Marii Braun-Gałkowskiej (1992), która postawy rodzicielskie sprowadziła do czterech wymiarów: 1) bliskości, wyrażającej się w dystansie emocjonalnym między rodzicami a dziećmi, 2) pomocy jaką rodzice udzielają dzieciom, 3) kierowania czyli stopniu ingerowania rodziców w decyzje dzieci i zakres zostawianej dzieciom samodzielności oraz 4) wymagań stawianych dzieciom i kierowanych wobec nich oczekiwań przez rodziców. Autorka zwróciła uwagę na właściwy stopień nasilenia tych postaw. Jej zdaniem postawy skrajne (niewłaściwe) charakteryzuje z jednej strony nadmiar, a $\mathrm{z}$ drugiej niedomiar. Na tych wymiarach można oznaczyć przeciwstawne sobie postawy rodzicielskie niekorzystne $\mathrm{z}$ wychowawczego punktu widzenia, takie jak:

1) z jednej strony odrzucenie dziecka, niechęć, obcość - z drugiej nadmierna bliskość, lepkość emocjonalna;

2) brak pomocy i opieki - nadmierna opiekuńczość, za duże ochranianie;

3) brak norm, zupełna swoboda - dyrygowanie, nadmierne zarządzanie;

4) całkowity brak wymagań - nadmierne wymagania i żądania.

Najwłaściwsze są postawy pośrednie, mieszczące się pomiędzy tymi skrajnościami: właściwa bliskość, odpowiednia pomoc, rozumna swoboda 
i stosowne wymagania. „Pozytywne postawy występujące razem można dopiero określić jako postawę dojrzałej miłości” (Braun-Gałkowska 1992, s. 34). Postawa taka jest najbardziej korzystna dla prawidłowego rozwoju dziecka.

Postawy rodzicielskie kształtowane są wraz z historią życia rodziców zależą od ich psychologicznych oraz interpersonalnych zasobów, podmiotowych właściwości dzieci (temperament, płeć, wiek, możliwości rozwojowe), jak również kontekstu źródeł stresu i wsparcia udzielanego rodzinie (Plopa 2005). Istotną rolę $\mathrm{w}$ kształtowaniu się postaw rodzicielskich odgrywa dynamiczny proces przemian społecznych, który ze względu na swoją specyfikę często uniemożliwia osiągnięcie względnej stabilizacji ekonomicznej, będącej ważnym elementem poczucia bezpieczeństwa. Wymuszona mobilność związana $\mathrm{z}$ wykonywaniem pracy $\mathrm{z}$ dala od miejsca zamieszkania zazwyczaj skutkuje osłabieniem czy wręcz zanikiem więzi rodzinnych. Również wzrost intensywności aktywności zawodowej coraz częściej prowadzi do nieporozumień i konfliktów w życiu rodzinnym. Ponadto system edukacji i zatrudnienia staje się pełen sprzeczności, a rozwijając się bez określonej strategii, nie daje możliwości indywidualnego długoterminowego planowania (Beck 2004). Wszystko to może w konsekwencji prowadzić do braku bezpieczeństwa ontologicznego, które oznacza brak poczucia trwania i porządku zdarzeń, w tym zdarzeń wykraczających poza obszar bezpośredniego doświadczenia jednostki. Człowiek, kierując się pragmatyzmem, ogranicza swoje reakcje czy działania, co w gruncie rzeczy sprowadza się do porządkowania tylko tej rzeczywistości, w której bezpośrednio funkcjonuje (Giddens 2007). Brak szerzej rozumianej stabilności, czyli spokoju egzystencjalnego, może doprowadzić do poczucia lęku (Rosicki 2010), który znacznie ogranicza możliwości realizacji planów życiowych, co z kolei negatywnie wpływa na poczucie samoakceptacji (Krasuska-Betiuk 2018).

Analizując przemiany życia społecznego zachodzące współcześnie coraz częściej używa się terminu „społeczeństwo ryzyka”, podkreślającego wzrost liczby zagrożeń. Typowe dla industrializmu priorytety polityczne, związane m.in. z równością szans, wzrostem gospodarczym, miejscami pracy nie znikają lecz są uzupełniane lub zastępowane przez nowe, polegające na wykrywaniu zagrożeń, szacowaniu ryzyka ich wystąpienia oraz szukaniu skutecznych sposobów przeciwdziałania tym zagrożeniom (Hryniewicz 2014).

W artykule zwrócono uwagę na jeden aspekt struktury osobowości rodziców, który dotyczy poziomu ich samoakceptacji. Wyniki badań prowadzonych w tym obszarze wskazują, że wyższa samoakceptacja, czyli mniejsza rozbieżność między „ja realnym” a „ja idealnym”, prowadzi do zmniejszenia stanów napięcia $\mathrm{w}$ organizmie, uwalnia od konieczności stosowania postaw 
obronnych i wpływa pozytywnie na rozwój aspiracji życiowych (Kot, Lenda 2017). Można założyć, że poziom samoakceptacji ze względu na swoją naturę będzie wpływał modyfikująco na przejawiane przez rodziców postawy rodzicielskie wobec własnych dzieci. W prezentowanym tekście podjęto próbę analizy postaw rodzicielskich małżonków o wyższym i niższym poziomie samoakceptacji.

\section{Metodologia badań}

Celem było ustalenie zależności pomiędzy poziomem samoakceptacji małżonków a przejawianymi przez nich postawami rodzicielskimi. Ponieważ poczucie samoakceptacji stanowi istotny element struktury osobowości (Hreciński, Uchnast 2012), główny problem badawczy określono następująco: $C z y$ postawy rodzicielskie małżonków o wyższym poziomie samoakceptacji różniq się od postaw rodzicielskich małżonków o niższym poziomie samoakceptacji? Wykorzystując idee związane z psychologią humanistyczną (Dakowicz 2000) przyjęto, że małżonkowie o wyższym poziomie samoakceptacji podejmując funkcje rodzicielskie, dysponują większym potencjałem wychowawczym, niż małżonkowie o niższym poziomie samoakceptacji. W związku z tym sformułowano hipotezę: Małżonkowie o wyższym poziomie samoakceptacji różniq się pod względem postaw rodzicielskich od małżonków o niższym poziomie samoakceptacji. Postawy rodzicielskie małżonków o wyższym poziomie samoakceptacji częściej charakteryzują się umiarem we wszystkich wymiarach postawy rodzicielskiej: bliskości, pomocy, kierowaniu i wymaganiach, niż postawy rodzicielskie matżonków o niższym poziomie samoakceptacji.

Podejmując postawiony problem, przeprowadzono badania wśród 75 rodzin mieszkających w Białymstoku i najbliższych okolicach spełniających następujące kryteria: wiek obojga małżonków do 45 lat, wykształcenie średnie lub wyższe, staż małżeński nie krótszy niż 10 lat, aktywność zawodowa obojga małżonków, posiadanie dwójki dzieci w przedziale wiekowym od 10 do 18 lat $^{1}$. Do badań wykorzystano Test Przymiotnikowy ACL H.G. Gougha i A.B. Heilbruna (Juros, Oleś 1993) oraz Skalę Postaw Rodzinnych (Braun-Gałkowska 2002). Test Przymiotnikowy ACL H.G. Gougha i A.B. Heilbruna zawiera listę 300 przymiotników charakteryzujących ludzkie cechy i zachowania, z której osoba badana dwukrotnie wybiera przymiotniki. Najpierw zgodnie z instruk-

1 Badania przeprowadzili w 2015 r. uczestnicy seminarium magisterskiego kierowanego przez dra Andrzeja Dakowicza w Zakładzie Psychologii Społecznej i Rozwoju Człowieka na Wydziale Pedagogiki i Psychologii Uniwersytetu w Białymstoku. 
cją "Jaka jest”, a następnie zgodnie $\mathrm{z}$ instrukcją „Jaka chciałaby być". W ten sposób powstają dwa profile osobowości: realnej i idealnej. Porównanie otrzymanych profili, przy wykorzystaniu odpowiedniego wzoru, określa stopień ich rozbieżności, co wskazuje na poziom samoakceptacji. Im rozbieżność profili jest mniejsza, tym większy jest stopień samoakceptacji badanej osoby (Drwal 1995). Z kolei Skala Postaw Rodzinnych służy do pomiaru postaw rodzicielskich $\mathrm{w}$ aspekcie behawioralnym. Badani na jedenastostopniowej skali określają nasilenie postawy rodzicielskiej danej osoby w czterech wymiarach: bliskości, pomocy, swobody i wymagań. Uzyskana ilość punktów decyduje o nasileniu danego wymiaru postawy ${ }^{2}$. Zarówno nadmiar, jak i niedomiar występujący $\mathrm{w}$ jakimkolwiek wymiarze postawy rodzicielskiej nie wpływa pozytywnie na przebieg procesu wychowawczego. Najbardziej pożądany jest umiar, który charakteryzuje: 1) właściwa bliskość, 2) odpowiednia pomoc, 3) rozumna swoboda, 4) stosowne wymagania (Braun-Gałkowska 2002). Skala Postaw Rodzinnych realizuje postulat systemowego podejścia do rodziny (Margasiński 2015), co wyraża się w możliwości porównania sposobu odbierania określonej postawy rodzicielskiej przez różnych członków rodziny, np. na temat postawy matki wobec dziecka otrzymujemy informację od matki, ojca i dziecka (Dakowicz 2004). Poznanie poglądów wszystkich członków rodziny na temat przejawianych postaw rodzicielskich stwarza okazję do lepszego zrozumienia rzeczywistości wychowawczej w rodzinie (Halicka i in. 2013).

Wyniki badań opracowano przy użyciu programu komputerowego SPSS 24.0 PL for Windows, za pomocą którego obliczono wartość testu chi-kwadrat dla porównywanych grup (Rycielski, Brzezicka 2013).

\section{Wyniki badań}

Uzyskane wyniki badań wskazują na zaistniałą prawidłowość w ocenie postaw rodzicielskich matek oraz ojców w percepcji matek, ojców i dzieci. Postawy rodzicielskie matek, w wymiarze bliskości, najczęściej charakteryzowane były w kategorii nadmiaru, a następnie umiaru i niedomiaru, zarówno przez badane matki, ojców oraz dzieci. W przypadku trzech pozostałych wymiarów postawy rodzicielskiej: pomocy, kierowaniu i wymaganiach, badanym matkom przypisywany był najczęściej umiar, a następnie nadmiar i niedomiar (tabele 1-3).

2 Nadmiar: 1-3 pkt, umiar: 4-8 pkt, niedomiar: 9-11 pkt. 
Lidia Dakowicz, Andrzej Dakowicz

Tabela 1. Postawy matek wobec dzieci w percepcji matek

\begin{tabular}{|c|c|c|c|c|c|}
\hline \multirow{2}{*}{$\begin{array}{c}\text { Wymiary } \\
\text { postawy } \\
\text { rodzicielskiej }\end{array}$} & \multirow[t]{2}{*}{ Kategorie } & \multicolumn{2}{|c|}{$\begin{array}{c}\text { Matki o wyższym poziomie } \\
\text { samoakceptacji }\end{array}$} & \multicolumn{2}{|c|}{$\begin{array}{c}\text { Matki o niższym poziomie } \\
\text { samoakceptacji }\end{array}$} \\
\hline & & $\mathrm{N}$ & $\%$ & $\mathrm{~N}$ & $\%$ \\
\hline \multirow[t]{4}{*}{ Bliskość } & nadmiar & 32 & 53,3 & 33 & 55,0 \\
\hline & umiar & 28 & 46,7 & 27 & 45,0 \\
\hline & niedomiar & 0 & 0,0 & 0 & 0,0 \\
\hline & razem & 60 & 100 & 60 & 100 \\
\hline \multicolumn{6}{|c|}{$\mathrm{chi}^{2}=0,04, \mathrm{df}=1, \mathrm{p}=$ n.i. } \\
\hline \multirow[t]{4}{*}{ Pomoc } & nadmiar & 24 & 40,0 & 24 & 40,0 \\
\hline & umiar & 33 & 55,0 & 34 & 56,7 \\
\hline & niedomiar & 3 & 5,0 & 2 & 3,3 \\
\hline & razem & 60 & 100 & 60 & 100 \\
\hline \multicolumn{6}{|c|}{$\mathrm{chi}^{2}=0,21, \mathrm{df}=2, \mathrm{p}=$ n.i. } \\
\hline \multirow[t]{4}{*}{ Kierowanie } & nadmiar & 10 & 16,7 & 18 & 30,0 \\
\hline & umiar & 42 & 70,0 & 38 & 63,3 \\
\hline & niedomiar & 8 & 13,3 & 4 & 6,7 \\
\hline & razem & 60 & 100 & 60 & 100 \\
\hline \multicolumn{6}{|c|}{$\mathrm{chi}^{2}=3,82, \mathrm{df}=2, \mathrm{p}=$ n.i. } \\
\hline \multirow[t]{4}{*}{ Wymagania } & nadmiar & 15 & 25,0 & 27 & 45,0 \\
\hline & umiar & 44 & 73,3 & 33 & 55,0 \\
\hline & niedomiar & 1 & 1,7 & 0 & 0,0 \\
\hline & razem & 60 & 100 & 60 & 100 \\
\hline \multicolumn{6}{|c|}{$\mathrm{chi}^{2}=6,00, \mathrm{df}=2, \mathrm{p}<0,05$} \\
\hline
\end{tabular}

Źródło: opracowanie własne.

Tabela 2. Postawy matek wobec dzieci w percepcji ojców

\begin{tabular}{|c|c|c|c|c|c|}
\hline \multirow{2}{*}{$\begin{array}{c}\text { Wymiary } \\
\text { postawy } \\
\text { rodzicielskiej }\end{array}$} & \multirow[t]{2}{*}{ Kategorie } & \multicolumn{2}{|c|}{$\begin{array}{c}\text { Matki o wyższym poziomie } \\
\text { samoakceptacji }\end{array}$} & \multicolumn{2}{|c|}{$\begin{array}{l}\text { Matki o niższym poziomie } \\
\text { samoakceptacji }\end{array}$} \\
\hline & & $\mathrm{N}$ & $\%$ & $\mathrm{~N}$ & $\%$ \\
\hline \multirow[t]{4}{*}{ Bliskość } & nadmiar & 39 & 65,0 & 34 & 56,7 \\
\hline & umiar & 19 & 31,7 & 26 & 43,3 \\
\hline & niedomiar & 2 & 3,3 & 0 & 0,0 \\
\hline & razem & 60 & 100 & 60 & 100 \\
\hline \multicolumn{6}{|c|}{$\mathrm{chi}^{2}=3,43, \mathrm{df}=2, \mathrm{p}=$ n.i. } \\
\hline \multirow[t]{4}{*}{ Pomoc } & nadmiar & 30 & 50,0 & 28 & 46,7 \\
\hline & umiar & 26 & 43,3 & 30 & 50,0 \\
\hline & niedomiar & 4 & 6,7 & 2 & 3,3 \\
\hline & razem & 60 & 100 & 60 & 100 \\
\hline \multicolumn{6}{|c|}{$\mathrm{chi}^{2}=1,02, \mathrm{df}=2, \mathrm{p}=$ n.i. } \\
\hline \multirow[t]{4}{*}{ Kierowanie } & nadmiar & 18 & 30,0 & 16 & 26,7 \\
\hline & umiar & 32 & 53,3 & 40 & 66,7 \\
\hline & niedomiar & 10 & 16,7 & 4 & 6,7 \\
\hline & razem & 60 & 100 & 60 & 100 \\
\hline \multicolumn{6}{|c|}{$\mathrm{chi}^{2}=3,58, \mathrm{df}=2, \mathrm{p}=$ n.i. } \\
\hline
\end{tabular}


Postawy rodzicielskie małżonków o wyższym i niższym poziomie samoakceptacji

\begin{tabular}{|c|c|c|c|c|c|}
\hline \multirow{2}{*}{$\begin{array}{c}\text { Wymiary } \\
\text { postawy } \\
\text { rodzicielskiej }\end{array}$} & Kategorie & \multicolumn{2}{|c|}{$\begin{array}{c}\text { Matki o wyższym poziomie } \\
\text { samoakceptacji }\end{array}$} & \multicolumn{2}{c|}{$\begin{array}{c}\text { Matki o niższym poziomie } \\
\text { samoakceptacji }\end{array}$} \\
\hline \multirow{3}{*}{ Wymagania } & nadmiar & $\mathrm{N}$ & $\%$ & $\mathrm{~N}$ & $\%$ \\
\cline { 2 - 6 } & umiar & 39 & 31,7 & 28 & 46,7 \\
\cline { 2 - 5 } & niedomiar & 2 & 65,0 & 32 & 53,3 \\
\cline { 2 - 6 } & razem & 60 & 100 & 0 & 0,0 \\
\hline \multicolumn{4}{|c|}{$\mathrm{chi}^{2}=4,41, \mathrm{df}=2, \mathrm{p}=$ n.i. } \\
\hline
\end{tabular}

Źródło: opracowanie własne.

Tabela 3. Postawy matek wobec dzieci w percepcji dzieci

\begin{tabular}{|c|c|c|c|c|c|}
\hline \multirow{2}{*}{$\begin{array}{c}\text { Wymiary } \\
\text { postawy } \\
\text { rodzicielskiej }\end{array}$} & \multirow[t]{2}{*}{ Kategorie } & \multicolumn{2}{|c|}{$\begin{array}{l}\text { Matki o wyższym poziomie } \\
\text { samoakceptacji }\end{array}$} & \multicolumn{2}{|c|}{$\begin{array}{l}\text { Matki o niższym poziomie } \\
\text { samoakceptacji }\end{array}$} \\
\hline & & $\mathrm{N}$ & $\%$ & $\mathrm{~N}$ & $\%$ \\
\hline \multirow[t]{4}{*}{ Bliskość } & nadmiar & 57 & 47,5 & 71 & 59,2 \\
\hline & umiar & 61 & 50,8 & 47 & 39,2 \\
\hline & niedomiar & 2 & 1,7 & 2 & 1,7 \\
\hline & razem & 120 & 100 & 120 & 100 \\
\hline \multicolumn{6}{|c|}{$\mathrm{chi}^{2}=3,35, \mathrm{df}=2, \mathrm{p}=$ n.i. } \\
\hline \multirow[t]{4}{*}{ Pomoc } & nadmiar & 49 & 40,8 & 63 & 52,5 \\
\hline & umiar & 62 & 51,7 & 50 & 41,7 \\
\hline & niedomiar & 9 & 7,5 & 7 & 5,8 \\
\hline & razem & 120 & 100 & 120 & 100 \\
\hline \multicolumn{6}{|c|}{$\mathrm{chi}^{2}=3,29, \mathrm{df}=2, \mathrm{p}=$ n.i. } \\
\hline \multirow[t]{4}{*}{ Kierowanie } & nadmiar & 23 & 19,2 & 54 & 45,0 \\
\hline & umiar & 83 & 69,2 & 57 & 47,5 \\
\hline & niedomiar & 14 & 11,7 & 9 & 7,5 \\
\hline & razem & 120 & 100 & 120 & 100 \\
\hline \multicolumn{6}{|c|}{$\mathrm{chi}^{2}=18,40, \mathrm{df}=2, \mathrm{p}<0,001$} \\
\hline \multirow[t]{4}{*}{ Wymagania } & nadmiar & 44 & 36,7 & 60 & 50,0 \\
\hline & umiar & 67 & 55,8 & 51 & 42,5 \\
\hline & niedomiar & 9 & 7,5 & 9 & 7,5 \\
\hline & razem & 120 & 100 & 120 & 100 \\
\hline
\end{tabular}

Źródło: opracowanie własne.

Różnice osiągające poziom istotności statystycznej pomiędzy postawami rodzicielskim matek o wyższym i niższym poziomie samoakceptacji zarejestrowano $\mathrm{w}$ wymiarze wymagań $\mathrm{w}$ percepcji matek (tabela 1 ) oraz w wymiarze kierowania w percepcji dzieci (tabela 3). Matki o niższym poziomie samoakceptacji zdecydowanie częściej niż matki o wyższym poziomie samoakceptacji charakteryzowały siebie jako nadmiernie wymagające $(\mathrm{p}<0,05)$. Dzieci ma- 
tek o niższym poziomie samoakceptacji zdecydowanie częściej niż dzieci matek o wyższym poziomie samoakceptacji postrzegały swoje matki jako kierujące nimi nadmiernie $(\mathrm{p}<0,001)$.

Postawy rodzicielskie ojców, we wszystkich wymiarach, najczęściej charakteryzowane były w kategorii umiaru, następnie nadmiaru i niedomiaru zarówno przez badanych ojców, matki oraz dzieci (tabela 4, 5, 6).

Tabela 4. Postawy ojców wobec dzieci w percepcji ojców

\begin{tabular}{|c|c|c|c|c|c|}
\hline \multirow{2}{*}{$\begin{array}{c}\text { Wymiary } \\
\text { postawy } \\
\text { rodzicielskiej }\end{array}$} & \multirow[t]{2}{*}{ Kategorie } & \multicolumn{2}{|c|}{$\begin{array}{l}\text { Ojcowie o wyższym poziomie } \\
\text { samoakceptacji }\end{array}$} & \multicolumn{2}{|c|}{$\begin{array}{c}\text { Ojcowie o niższym poziomie } \\
\text { samoakceptacji }\end{array}$} \\
\hline & & $\mathrm{N}$ & $\%$ & $\mathrm{~N}$ & $\%$ \\
\hline \multirow[t]{4}{*}{ Bliskość } & nadmiar & 22 & 36,7 & 34 & 56,7 \\
\hline & umiar & 37 & 61,7 & 26 & 43,3 \\
\hline & niedomiar & 1 & 1,7 & 0 & 0,0 \\
\hline & razem & 60 & 100 & 60 & 100 \\
\hline \multicolumn{6}{|c|}{$\mathrm{chi}^{2}=5,49, \mathrm{df}=2, \mathrm{p}=$ n.i. } \\
\hline \multirow[t]{4}{*}{ Pomoc } & nadmiar & 15 & 25,0 & 28 & 46,7 \\
\hline & umiar & 42 & 70,0 & 28 & 46,7 \\
\hline & niedomiar & 3 & 5,0 & 4 & 6,7 \\
\hline & razem & 60 & 100 & 60 & 100 \\
\hline \multicolumn{6}{|c|}{$\mathrm{chi}^{2}=6,87, \mathrm{df}=2, \mathrm{p}<0,04$} \\
\hline \multirow[t]{4}{*}{ Kierowanie } & nadmiar & 11 & 18,3 & 9 & 15,0 \\
\hline & umiar & 44 & 73,3 & 41 & 68,3 \\
\hline & niedomiar & 5 & 8,3 & 10 & 16,7 \\
\hline & razem & 60 & 100 & 60 & 100 \\
\hline \multicolumn{6}{|c|}{$\mathrm{chi}^{2}=1,97, \mathrm{df}=2, \mathrm{p}=$ n.i. } \\
\hline \multirow[t]{4}{*}{ Wymagania } & nadmiar & 17 & 28,3 & 25 & 41,7 \\
\hline & umiar & 39 & 65,0 & 35 & 58,3 \\
\hline & niedomiar & 4 & 6,7 & 0 & 0,0 \\
\hline & razem & 60 & 100 & 60 & 100 \\
\hline \multicolumn{6}{|c|}{$\mathrm{chi}^{2}=5,97, \mathrm{df}=2, \mathrm{p}=$ n.i. } \\
\hline
\end{tabular}

Źródło: opracowanie własne.

Tabela 5. Postawy ojców wobec dzieci w percepcji matek

\begin{tabular}{|c|c|c|c|c|c|}
\hline \multirow{2}{*}{$\begin{array}{c}\text { Wymiary } \\
\text { postawy } \\
\text { rodzicielskiej }\end{array}$} & \multirow[t]{2}{*}{ Kategorie } & \multicolumn{2}{|c|}{$\begin{array}{c}\text { Ojcowie o wyższym poziomie } \\
\text { samoakceptacji }\end{array}$} & \multicolumn{2}{|c|}{$\begin{array}{c}\text { Ojcowie o niższym poziomie } \\
\text { samoakceptacji }\end{array}$} \\
\hline & & $\mathrm{N}$ & $\%$ & $\mathrm{~N}$ & $\%$ \\
\hline \multirow[t]{4}{*}{ Bliskość } & nadmiar & 15 & 25,0 & 21 & 35,0 \\
\hline & umiar & 44 & 73,3 & 39 & 65,0 \\
\hline & niedomiar & 1 & 1,7 & 0 & 0,0 \\
\hline & razem & 60 & 100 & 60 & 100 \\
\hline
\end{tabular}


Postawy rodzicielskie małżonków o wyższym i niższym poziomie samoakceptacji

\begin{tabular}{|c|c|c|c|c|c|}
\hline \multirow{2}{*}{$\begin{array}{c}\text { Wymiary } \\
\text { postawy } \\
\text { rodzicielskiej }\end{array}$} & \multirow[t]{2}{*}{ Kategorie } & \multicolumn{2}{|c|}{$\begin{array}{c}\text { Ojcowie o wyższym poziomie } \\
\text { samoakceptacji }\end{array}$} & \multicolumn{2}{|c|}{$\begin{array}{c}\text { Ojcowie o niższym poziomie } \\
\text { samoakceptacji }\end{array}$} \\
\hline & & $\mathrm{N}$ & $\%$ & $\mathrm{~N}$ & $\%$ \\
\hline \multirow[t]{4}{*}{ Pomoc } & nadmiar & 13 & 21,7 & 13 & 21,7 \\
\hline & umiar & 44 & 73,3 & 45 & 75,0 \\
\hline & niedomiar & 3 & 5,0 & 2 & 3,3 \\
\hline & razem & 60 & 100 & 60 & 100 \\
\hline \multicolumn{6}{|c|}{$\mathrm{chi}^{2}=0,21, \mathrm{df}=2, \mathrm{p}=$ n.i. } \\
\hline \multirow[t]{4}{*}{ Kierowanie } & nadmiar & 12 & 20,0 & 8 & 13,3 \\
\hline & umiar & 42 & 70,0 & 45 & 75,0 \\
\hline & niedomiar & 6 & 10,0 & 7 & 11,7 \\
\hline & razem & 60 & 100 & 60 & 100 \\
\hline \multicolumn{6}{|c|}{$\mathrm{chi}^{2}=0,98, \mathrm{df}=2, \mathrm{p}=$ n.i. } \\
\hline \multirow[t]{4}{*}{ Wymagania } & nadmiar & 19 & 31,7 & 18 & 30,0 \\
\hline & umiar & 39 & 65,0 & 42 & 70,0 \\
\hline & niedomiar & 2 & 3,3 & 0 & 0 \\
\hline & razem & 60 & 100 & 60 & 100 \\
\hline
\end{tabular}

Źródło: opracowanie własne.

Tabela 6. Postawy ojców wobec dzieci w percepcji dzieci

\begin{tabular}{|c|c|c|c|c|c|}
\hline \multirow{2}{*}{$\begin{array}{c}\text { Wymiary } \\
\text { postawy } \\
\text { rodzicielskiej }\end{array}$} & \multirow[t]{2}{*}{ Kategorie } & \multicolumn{2}{|c|}{$\begin{array}{c}\text { Ojcowie o wyższym poziomie } \\
\text { samoakceptacji }\end{array}$} & \multicolumn{2}{|c|}{$\begin{array}{c}\text { Ojcowie o niższym poziomie } \\
\text { samoakceptacji }\end{array}$} \\
\hline & & $\mathrm{N}$ & $\%$ & $\mathrm{~N}$ & $\%$ \\
\hline \multirow[t]{4}{*}{ Bliskość } & nadmiar & 39 & 32,5 & 47 & 39,2 \\
\hline & umiar & 78 & 65,0 & 70 & 58,3 \\
\hline & niedomiar & 3 & 2,5 & 3 & 2,5 \\
\hline & razem & 120 & 100 & 120 & 100 \\
\hline \multicolumn{6}{|c|}{$\mathrm{chi}^{2}=1,18, \mathrm{df}=2, \mathrm{p}=$ n.i. } \\
\hline \multirow[t]{4}{*}{ Pomoc } & nadmiar & 32 & 26,7 & 29 & 24,2 \\
\hline & umiar & 81 & 67,5 & 84 & 70,0 \\
\hline & niedomiar & 7 & 5,8 & 7 & 5,8 \\
\hline & razem & 120 & 100 & 120 & 100 \\
\hline \multicolumn{6}{|c|}{$\mathrm{chi}^{2}=0,20, \mathrm{df}=2, \mathrm{p}=$ n.i. } \\
\hline \multirow[t]{4}{*}{ Kierowanie } & nadmiar & 24 & 20,0 & 29 & 24,2 \\
\hline & umiar & 76 & 63,3 & 73 & 60,8 \\
\hline & niedomiar & 20 & 16,7 & 18 & 15,0 \\
\hline & razem & 120 & 100 & 120 & 100 \\
\hline \multicolumn{6}{|c|}{$\mathrm{chi}^{2}=0,64, \mathrm{df}=2, \mathrm{p}=$ n.i. } \\
\hline \multirow[t]{4}{*}{ Wymagania } & nadmiar & 49 & 40,8 & 41 & 34,2 \\
\hline & umiar & 66 & 55,0 & 70 & 58,3 \\
\hline & niedomiar & 5 & 4,2 & 9 & 7,5 \\
\hline & razem & 120 & 100 & 120 & 100 \\
\hline
\end{tabular}

Źródło: opracowanie własne. 
Różnice osiągające poziom istotności statystycznej pomiędzy postawami rodzicielskim ojców o wyższym i niższym poziomie samoakceptacji zarejestrowano jedynie w percepcji ojców. Ojcowie o niższym poziomie samoakceptacji zdecydowanie częściej niż ojcowie o wyższym poziomie samoakceptacji charakteryzowali siebie jako nadmiernie udzielający pomocy $(\mathrm{p}<0,04)$.

\section{Podsumowanie}

Sformułowana na wstępie hipoteza mówiąca o tym, że postawy rodzicielskie małżonków o wyższym poziomie samoakceptacji częściej charakteryzują się umiarem we wszystkich wymiarach postawy rodzicielskiej: bliskości, pomocy, kierowaniu i wymaganiach niż postawy rodzicielskie małżonków o niższym poziomie samoakceptacji, potwierdziła się w znacznej części.

Postawy rodzicielskie matek o wyższym i niższym poziomie samoakceptacji wobec własnych dzieci, w percepcji zarówno matek, ojców jak i samych dzieci były określane podobnie. Uzyskany wynik (we wszystkich wymiarach: bliskości, pomocy, kierowaniu oraz wymaganiach) w największym stopniu wyrażany był $\mathrm{w}$ kategorii umiaru i nadmiaru oraz $\mathrm{w}$ niewielkim stopniu $\mathrm{w}$ kategorii niedomiaru. Matki o niższym poziomie samoakceptacji znacznie częściej, niż matki o wyższym poziomie samoakceptacji stawiały swoim dzieciom nadmierne wymagania. Skłonność matek o niższym poziomie samoakceptacji do stawiania nadmiernych wymagań swoim dzieciom, może wynikać z chęci zmotywowania ich do osiągania konkretnych celów w swoim życiu, dzięki czemu dzieci będą mogły doświadczać satysfakcji z ich osiągnięcia. Prawdopodobnie matki o niższym poziomie samoakceptacji chcą stworzyć swoim dzieciom korzystne warunki ku temu, by mogły one siebie zaakceptować i czuć się w tym wymiarze osobowościowym lepiej niż ich matki. Niestety jawi się tu ryzyko stawiania przez matki wymagań przekraczających potencjalne możliwości dziecka, co nie sprzyja jego osobowemu rozwojowi. Dziecko potrzebuje nie tylko wymagań, ale przede wszystkim wspierania odpowiedniego do swoich możliwości (Stepulak 2017), bez którego nierzadko nie jest w stanie sprostać rodzicielskim wymaganiom. Może to negatywnie wpływać na proces kształtowania kompetencji społecznych u dzieci (Jastrzębski, Baranowska 2015). Za zaistniały, niekorzystny stan rzeczy, dzieci skłonne są obwiniać siebie (Stradomska 2017), co w konsekwencji może prowokować powstanie trudnych do wyleczenia zaburzeń psychicznych (Brytek-Matera, Charzyńska 2009).

Zaobserwowane istotne statystycznie różnice $\mathrm{w}$ postrzeganiu postaw rodzicielskich matek o niższym poziomie samoakceptacji przez dzieci, które przypisują matkom nadmiar kierowania, można by tłumaczyć następująco: 
prawdopodobnie przez pryzmat braku osobistych doświadczeń w efektywnym kierowaniu sobą matki o niższym poziomie samoakceptacji zakładają, że dziećmi trzeba kierować, bo same nie wiedzą co i jak należy robić. Prowadzi to do pozbawienia swoich dzieci możliwości nabywania zdolności podejmowania decyzji, ponoszenia ich konsekwencji i brania odpowiedzialności za nie. Ostatecznie może to wywołać brak poczucia skuteczności własnych działań oraz zniechęcenie do przejawiania inicjatywy, kształtując wręcz postawę wyuczonej bezradności (Warchala, Krupka-Matuszczyk 2015).

Postawy rodzicielskie ojców o wyższym i niższym poziomie samoakceptacji w wymiarze: bliskości, pomocy, kierowania i wymagań, były określane podobnie przez wszystkie badane osoby. Najczęściej wybierano kategorię umiaru i nadmiaru, natomiast $\mathrm{w}$ niewielkim stopniu niedomiaru. Jedyna istotna statystycznie różnica wystąpiła w percepcji ojców w odniesieniu do wymiaru pomocy. Ojcowie o niższym poziomie samoakceptacji zdecydowanie częściej niż ojcowie o wyższym poziomie samoakceptacji uważali, że udzielają swoim dzieciom pomocy w nadmiarze. Warto podkreślić, że nie potwierdziły tego ani badane matki, ani dzieci. Prawdopodobnie ojcowie o niższym poziomie samoakceptacji, przypisując sobie większe zaangażowanie w pomoc dzieciom, szukali okazji, by poprawić własne samopoczucie. Subiektywne przekonanie o osobistym zaangażowaniu w pomoc własnym dzieciom może wpłynąć na włączenie do struktury „ja” (Oleś 2011) siebie w roli dobrego ojca. Prowadzi to do wzbogacenia struktury osobowości o pozytywny element dający namiastkę poczucia spełnienia siebie $\mathrm{w}$ wymiarze rodzicielskim. Ponieważ w pozostałych wymiarach postawy rodzicielskiej: bliskości, kierowaniu i wymaganiach, ojcowie o niższym poziomie samoakceptacji najczęściej wskazywali na umiar, istnieje szansa, aby ich ojcostwo osiągnęło stan pełniejszego, harmonijnego rozwoju.

Jak pokazały wyniki przeprowadzonych badań, poziom samoakceptacji wpływa modyfikująco na postawy rodzicielskie. Warto zatem zwrócić szczególną uwagę na to, by małżonków cechował wysoki poziom samoakceptacji. Poczucie samoakceptacji powstaje pod wpływem wielu czynników, m.in. takich jak atmosfera życia rodzinnego (Wiśniewska 2017), przebieg procesu edukacji (Zawadzka i in. 2018), sposób korzystania ze środków masowego przekazu (Dakowicz, Dakowicz 2008; Śliwak i in. 2017), udział w grupie rówieśniczej (Walęcka-Matyja 2009). Jednak w największym stopniu poczucie samoakceptacji kształtowane jest w rodzinie pochodzenia (Martowska 2012), a ostatecznie podlega modyfikacji w procesie samowychowania (Grzywak-Kaczyńska 1988). Rzeczywistość ta stawia wyzwania rodzicom, którzy powinni podjąć pracę nad własnym rozwojem osobowości, w tym nad akceptacją siebie, by móc zaakceptować własne dzieci, stwarzając im tym samym najwłaściwsze śro- 
dowisko rozwoju i wychowania. Rodzice, przed którymi stoi niełatwe zadanie wychowawcze, potrzebują wsparcia ze strony odpowiednio przygotowanych do tego podmiotów. Rozwijająca się idea pedagogizacji rodziców jest dobrym przykładem takiego wsparcia (Skreczko 2001). Pedagogizacja rodziców, w Białymstoku i okolicach, prowadzona jest m.in. w ramach Podlaskiej Szkoły dla Rodziców i Wychowawców oraz na szczeblu samorządowym w ramach Białostockiej Akademii Rodziny, która regularnie i w atrakcyjny sposób wspiera funkcjonowanie rodzin na wielu płaszczyznach (Dakowicz, Dakowicz 2014), organizując różne formy doskonalenia osobistego, w tym warsztaty doskonalenia wychowawczego. Konkretnym przejawem działalności Białostockiej Akademii Rodziny są liczne oferty wykładów i szkoleń kierowanych bezpośrednio do małżonków pełniących funkcje wychowawcze, np. "Jak budować poczucie wartości u dziecka”; warsztat „Tato \& Córka”; „Trening skutecznego rodzica” (Białostocka Akademia Rodziny 2019).

Przygotowanie do odpowiedniego pełnienia ról rodzicielskich oraz pomoc $\mathrm{w}$ kształtowaniu właściwych postaw rodzicielskich jest również ważnym zadaniem edukacyjnym stojącym przed różnymi placówkami oświatowo-wychowawczymi. Może to mieć miejsce np. w szkole, podczas lekcji wychowawczych, spotkań z pedagogiem czy psychologiem, a w szczególności w trakcie realizacji przedmiotu wychowanie do życia w rodzinie. W placówkach tych powinno się położyć szczególny nacisk na wzrost samoakceptacji wychowanków, aby ułatwić im w przyszłości osiągnięcie prawidłowych postaw rodzicielskich.

\section{Bibliografia}

Beck U., (2004), Społeczeństwo ryzyka. W drodze do innej nowoczesności, Wydawnictwo Naukowe SCHOLAR, Warszawa.

Braun-Gałkowska M., (1992), Psychologiczna analiza systemów rodzinnych osób zadowolonych $i$ niezadowolonych $z$ małżeństwa, Towarzystwo Naukowe Katolickiego Uniwersytetu Lubelskiego, Lublin.

Braun-Gałkowska M., (2002), Metody poznawania systemu rodzinnego, Katolicki Uniwersytet Lubelski, Katedra Psychologii Wychowawczej i Rodziny, Lublin.

Brytek-Matera A., Charzyńska E., (2009), Związek pomiędzy niezadowoleniem z ciała i zmiennymi psychospołecznymi wspótwystępującymi z zaburzeniami odżywiania, „Roczniki Psychologiczne", 12(2), s. 129-150.

Dakowicz A., (2000), Płeć psychiczna a poziom samoaktualizacji, Trans Humana Wydawnictwo Uniwersyteckie, Białystok.

Dakowicz A. (red.), (2004), Systemowe ujęcie życia rodzinnego, [w:] Rodzina podlaska wobec różnych wyzwań egzystencjalnych, Wydawnictwo Uniwersyteckie Trans Humana, Białystok, s. 11-20.

Dakowicz L., Dakowicz A., (2008), Relacja dziecko - drugi człowiek a relacja dziecko - media drukowane i elektroniczne, [w:] Media elektroniczne - kreujace obraz rodziny i dziecka, J. Izdebska (red.), Wydawnictwo Uniwersyteckie Trans Humana, Białystok, ss. 54-59. 
Dakowicz L., Dakowicz A., (2014), Wychowanie do życia w rodzinie - wspólna troska białostockiej społeczności lokalnej o przyszłość młodego pokolenia, „Studia nad Rodziną”, 2(35), s. 65-76.

Drwal R.Ł., (1995), Adaptacja kwestionariuszy osobowości, Wydawnictwo Naukowe PWN, Warszawa.

Giddens A., (2007), Nowoczesność i tożsamość, Wydawnictwo Naukowe PWN, Warszawa.

Grzywak-Kaczyńska M., (1988), Trud rozwoju, Instytut Wydawniczy PAX, Warszawa.

Halicka M., Dakowicz L., Skreczko A., (2013), Świadomość wychowawcza białostockich rodzin. Raport $z$ badań, Wydawca Miasto Białystok, Białystok.

Hreciński P., Uchnast Z., (2012), Typy charakteru a obraz siebie, „Roczniki Psychologiczne”, 15(4), s. 95-115.

Hryniewicz J.T., (2014), Społeczeństwo ryzyka. Teoria, model, analiza krytyczna, „Przegląd Socjologiczny", 63(2), s. 9-33.

Jankowska M., (2013), Postawy rodzicielskie ojca a styl przywiazaniowy $w$ dorostych relacjach córki, „Kwartalnik Naukowy Fides et Ratio”, 1(13), s. 156-185.

Jastrzębski J., Baranowska M., (2015), Rola postaw rodzicielskich $w$ kształtowaniu poczucia kontroli u dzieci w wieku przedszkolnym, „Kwartalnik Naukowy Fides et Ratio”, 1(21), s. 6379.

Juros A., Oleś P., (1993), Struktura czynnikowa i skupieniowa Testu Przymiotnikowego ACL H.G. Gougha i A.B. Heilbruna, [w:] Z psychometrycznych problemów diagnostyki psychologicznej, J. Brzeziński, E. Hornowska (red.), Wydawnictwo Naukowe UAM, Poznań, s. 171201.

Kot P., Lenda J., (2017), Poczucie koherencji a aspiracje życiowe studentów, „Annales Universitatis Mariae Curie-Skłodowska”, 30(1), s. 129-145.

Krasuska-Betiuk M., (2018), Od poznania do konstytuowania siebie. Pedagogiczne implikacje dylematów samotożsamościowych wspótczesnego człowieka, „Studia z Teorii Wychowania”, 1(22), s. 111-131.

Margasiński A. (red.), (2015), Teoria i wybrane modele systemów rodzinnych, [w:] Rodzina w ujeciu systemowym. Teoria i badania, Pracownia Testów Psychologicznych Polskiego Towarzystwa Psychologicznego, Warszawa, s. 6-32.

Martowska K., (2012), Psychologiczne uwarunkowania kompetencji społecznych, Wydawnictwo Liberi Libri, Warszawa.

Oleś P.K., (2011), Wprowadzenie do psychologii osobowości, Wydawnictwo Naukowe SCHOLAR, Warszawa.

Plopa M., (2005), Psychologia rodziny. Teoria i badania, Wydawnictwo Elbląskiej Uczelni Humanistyczno-Ekonomicznej, Elbląg.

Rosicki R., (2010), O pojęciu i istocie bezpieczeństwa, „Przegląd Politologiczny”, 3, s. 24-32.

Rycielski P., Brzezicka A., (2013), Wnioskowanie statystyczne na danych jakościowych. Testy wykorzystujace rozkład chi-kwadrat, [w:] Statystyczny drogowskaz 1. Praktyczne wprowadzenie do wnioskowania statystycznego, S. Bedyńska, M. Cypryańska (red.), Wydawnictwo Akademickie Sedno Spółka z o.o., Warszawa, s. 135-157.

Skreczko A., (2001), Pedagogizacja rodziców w zakresie wychowania prorodzinnego dziecka, „Studia nad Rodziną", 1(8), s. 175-182.

Stepulak M.Z., (2017), Synergiczny obraz osobowego rozwoju ucznia, „General and Professional Education", 1, s. 54-60.

Stradomska M., (2017), Psychologiczne predyktory zachowań autodestrukcyjnych u dzieci i młodzieży - aspekt suicydogennych sekt, „Międzynarodowe Studia Społeczno-Humanistyczne", 24(1), s. 91-98. 
Śliwak J., Zarosińska D., Wysocka M., Partyka J., (2017), Poziom samooceny u osób korzystajq̨cych $z$ różnych form Internetu, „Studia Socialia Cracoviensia”, 2(17), s. 129-149.

Walęcka-Matyja K., (2009), Struktura rodziny a zróżnicowanie zachowań społecznych i osobowości młodzieży, Wydawnictwo Uniwersytetu Łódzkiego, Łódź.

Warchala A., Krupka-Matuszczyk I., (2015), Konsekwencje utraty sensu życia, „Czasopismo Psychologiczne", 21(1), s. 73-80.

Wiśniewska L.A., (2017), Rozwój niezadowolenia z ciała u dzieci - wplyw komentarzy rodziców i rola zabawek, „Psychologia Rozwojowa”, 4(22), s. 15-26.

Wojciszke B., Doliński D., (2008), Psychologia społeczna, [w:] Psychologia. Podręcznik akademic$k i$, t. 2, J. Strelau, D. Doliński (red.), Gdańskie Wydawnictwo Psychologiczne, Gdańsk, s. $293-447$.

Wilk J., (2016), Pedagogika rodziny, Wydawnictwo Episteme, Lublin.

Zawadzka D., Korzycka M., Oblacińska A., (2018), Poczucie sensu życia jako czynnik chroniqcy młodzież gimnazjalna przed stosowaniem i doznawaniem przemocy rówieśniczej, „Psychiatria i Psychologia Kliniczna”, 18(4), s. 340-353.

\section{Źródła internetowe}

Białostocka Akademia Rodziny (2019). Galeria. Fotorelacje z najciekawszych wydarzeń z życia Białostockiej Akademii Rodziny, http://rodzina.bialystok.pl (data pobrania: 2.01.2019) 